\title{
Pericarp Ultrastructure of Salvia Section Hemisphace (Mentheae; Nepetoideae; Lamiaceae)
}

\author{
Ahmet KAHRAMAN ${ }^{1,}{ }^{*}$, Hatice Nurhan BÜYÜKKARTAL ${ }^{2}$, Musa DOĞAN³ \\ ${ }^{1}$ Department of Biology, Faculty of Arts and Sciences, Uşak University, 64200, Uşak, Turkey \\ 2 Department of Biology, Faculty of Sciences, Ankara Univesity, 06100, Ankara, Turkey \\ ${ }^{3}$ Department of Biological Sciences, Faculty of Arts and Sciences, Middle East Technical Univesity, 06800, Ankara, Turkey
}

\begin{abstract}
Received: 16.12 .2017
Accepted: 16.12 .2018

Available online: 02.01 .2018

Published: 30.06 .2018

Abstract: The genus Salvia L. (sage), which belongs to the tribe Mentheae of the subfamily Nepetoideae within the family Lamiaceae, is well-known for its medicinal, ornamental, culinary and hallucinogenic uses. The section Hemisphace Benth. of this genus is respresented in Turkey by three species. The present study is conducted on two morphologically similar Salvia species belonging to this section: Salvia napifolia Jacq. and S. russellii Benth. (excluding S. verticillata L.). For this purpose, the pericarp ultrastructure of these species is investigated in detail with the help of light and transmission electron microscopy (TEM). Morphometric characters are analyzed using one-way Analysis of Variance (ANOVA) with Tukey's honestly significant difference (HSD) post-hoc test for multiple comparisons. The taxonomic potential of pericarp characteristics is discussed. The most prominent traits are the thickness of the pericarp, mesocarp and sclerenchyma region that permit the separation of the species studied. Myxocarpy (mucilage formation) is recognized on the surface of the wetted mericarps of both species. Mucilaginous cells reveal a moderate reaction but S. napifolia is of a somewhat thicker mucilaginous layer, about $0.20-0.34 \mathrm{~mm}$. This study represents the first comprehensive findings on the pericarp ultrastructure of the species examined.
\end{abstract}

Keywords: Lamiaceae, pericarp ultrastructure, Salvia, section Hemisphace, TEM, Turkey.

\section{Salvia Cinsi Hemisphace Seksiyonun (Mentheae; Nepetoideae; Lamiaceae) Perikarp İnce Yapısı}

Özet: Lamiaceae familyası içindeki Nepetoideae alt familyasının Mentheae oymağına ait olan Salvia L. (adaçayı) cinsi tıbbi, süs bitkisi, gıda ve halüsinojenik kullanımları nedeniyle ile iyi bilinmektedir. Bu cinsin Hemisphace Benth. seksiyonu Türkiye'de üç tür ile temsil edilir. Bu güncel çalışma, ilgili seksiyona ait morfolojik olarak birbirine benzeyen iki Salvia türü üzerine yürütülmüştür: Salvia napifolia Jacq. ve S. russellii Benth. (S. verticillata L. hariç). Bu amaç için, söz konusu türlerin perikap ince yapısı ışık ve geçirimli elektron mikroskobu (TEM) yardımıyla detaylı olarak araştırılmıştır. Morfometrik karakterler çoklu karşılaştırmalar için tek yönlü Varyans Analizi (ANOVA) ile Tukey'in tam olarak önemli fark (HSD) post-hoc testi kullanılarak analiz edilmiştir. Perikarp özelliklerinin taksonomik önemi tartışılmıştır. Çalışılan türlerin ayrımına izin veren en önemli özellikler; perikarp, mesokarp ve sklerenkima bölgesinin kalınlığıdır. Her iki türün ıslatılmış merikarplarının yüzeyinde miksokarpi (müsilaj oluşumu) görülmüştür. Müsilajlı hücreler orta düzeyde bir reaksiyon göstermiştir, fakat $S$. napifolia'daki müsilajlı tabaka biraz daha kalındır (yaklaşık 0.20-0.34 mm). Bu çalışma incelenen türlerin perikarp ince yapısı üzerine ilk detaylı bulguları sunmaktadır.

Anahtar kelimeler: Lamiaceae, perikarp ince yapısı, Salvia, Hemisphace seksiyonu, TEM, Türkiye.

\section{Introduction}

In Turkey, Salvia L. is called "adaçayı" and is often consumed as tea (Baytop, 1999). In the traditional Turkish folk medicine, it is used as antibacterial, stomachic, diuretic, spasmolitic, antiseptic, hemostatic, stimulant and carminative and in the treatment of sore throats, cough, colds and wounds (Ulubelen, 2003; Kotan et al., 2008; Topcu et al., 2008; Kirmizibekmez et al., 2012; Er, Tugay, Özcan, Ulukuş, \& Al-Juhaimi, 2013).

The genus Salvia is assigned to the tribe Mentheae of the subfamily Nepetoideae within the family Lamiaceae. Salvia is distinguished from the other 72 genera in the Mentheae by the presence of two aborted posterior stamens and a markedly elongated connective tissue separating thecae of the two expressed stamens that may form a lever mechanism of pollination for which the genus is best known (Walker \& Systsma, 2007). It is widely known as the largest genus of the Lamiaceae, consisting of approximately 1000 species restricted to five regions throughout the world: central and south America (approx. $550 \mathrm{spp}$., the most significant center of species diversity), western Asia (approx. 220 spp., mainly in Turkey, Iran, Russia, and Afghanistan), eastern Asia (approx. 100 spp., mainly in China and Japan), east and south Africa (approx. 60 spp.), and Europe (approx. 36 spp.) (Walker \& Systsma, 2007).

In western Asia, the most significant center of species diversity of the genus is found in Turkey with 100 species recognized until recently. The rate of Turkish endemic to Salvia species is 53\%. These species are divided into seven sections: Salvia Hedge (synonym Eusphace Benth.), Aethiopis Benth., Plethiosphace Benth., Drymosphace Benth., Horminum Benth., and Hemisphace Benth. (Boissier, 1879; Doğan et al., 2007). Leaf (pinnatisect, trisect or simple), calyx (membranous or thick textured, upper lip 2-sulcate or not, concave or not), corolla (upper lip falcate or not, tube squamulate or not, annulate or not) and stamen (type A, B or C) characteristics are the most significant means for 
separating these sections from each other. In Turkey, the section Hemisphace is respresented by three non-endemic species: Salvia napifolia Jacq., S. russellii Benth., and S. verticillata L. (Hedge, 1982).

It has been demonstrated that mericarp (nutlet) characters can be used successfully at many taxonomic levels, depending on the characters chosen and the variation present (Guerin, 2005). Ultrastructural studies on the pericarp have been carried out in various genera of the family Lamiceae and have proved the usefulness of pericarp characters for species and generic level in the family (Wagner, 1914; Bilimovitsch, 1935; Wojciechowska, 1958, 1961a, b, 1966, 1972; Makarova, 1967, Hedge \& Lamond, 1968; Hedge, 1970; Witztum, 1978; Ryding, 1992a, b, 1993a, b, 1995, 2001, 2010; Budantsev, 1993a, b; Budantsev \& Lobova, 1997; Duletić-Lauševic \& Marin, 1999; Mosquero, Juan, \& Pastor, 2002; Moon \& Hong, 2006). However, there have been only a few studies on the pericarp ultrastructure of the genus Salvia (Wojciechowska, 1958, 1966; Hedge, 1970; Oran, 1997; Ryding, 2010; Büyükkartal, Kahraman, Çölgeçen, Doğan, \& Karabacak, 2011; Hassan \& Al. Thobaiti, 2014). No detailed data have been recorded on the pericarp ultrastructure of S. napifolia and S. russellii belonging to the section Hemisphace of this genus. Therefore, this study aims to investigate the pericarp ultrastructure of these species that have not been comprehensively studied to date; by light and transmission electron microscopy and to assess the taxonomic importance of pericarp characters in their delimitation.

\section{Material and Methods}

Specimens of S. napifolia and S. russellii in the section Salvia of the genus Salvia were collected from their natural habitats during field investigations in Turkey. The collected specimens were pressed and dried on the basis of standard herbarium techniques (Davis \& Heywood, 1973) and kept in the herbarium of the Department of Biological Sciences, at the Middle East Technical University (METU) in Ankara. The source of each species is as follows; S. napifolia: Hatay, Samandağ to Yayladă̆, F. Celep 1646 and S. russelii: Van, Van to Gürpinar, A. Kahraman 1451.

\subsection{Light microscopy (LM)}

The mericarps of S. napifolia and S. russellii were first examined using a stereomicroscope to ensure that they were of normal size and maturity. For pericarp ultrastructure studies, the ripe mericarps were softened and placed for 24 hours in distilled water. Then, they were fixed in $3 \%$ glutaraldehyde (with $0.1 \mathrm{M} \mathrm{Na}-\mathrm{P}$ buffer) and $1 \%$ osmium tetroxide (with $0.1 \mathrm{M} \mathrm{Na-P}$ buffer). After that, they were dehydrated through a graduated ethanol series and embedded in Epon 812 (Luft, 1961). Transverse semi-thin sections for LM were obtained by sectioning of the embedded material. After that, these semi-thin sections were stained with methylene blue and toluidine blue and mounted permanently. By means of LM, the sections obtained were examined and photographed for the pericarp characteristics, such as thickness of the pericarp, mesocarp, sclerenchymatous region and endocarp and mucilaginous cells. According to Hedge (1970) and Ryding (2010), the terminology was adjusted for pericarp structure.
The method of Ryding (1992a) was followed to determine whether the formation of mucilage on their surface occurs when they were wetted. The amount of mericarp mucilage production by the species studied was compared. According to this method based on the extent of swelling of mucilaginous cells, there were four main types of reactions: (1) a strong reaction with mucilaginous cells $0.8-1.5 \mathrm{~mm}$ long, (2) a moderate reaction with mucilaginous cells $0.1-0.5 \mathrm{~mm}$ long, (3) a weak reaction with mucilaginous cells less than $0.1 \mathrm{~mm}$ long, and (4) a very weak reaction when no appreciable elongation of mucilaginous cells occured after swelling in water.

\subsection{Transmission Electron Microscopy (TEM)}

For TEM, ultra-thin sections were obtained by sectioning of the embedded material. Then, they were stained with uranyl acetate (Stempak \& Ward, 1964) and lead citrate (Sato, 1968). Next, they were examined with the aid of JEOL CX-100 TEM and micrographs were taken.

\subsection{Statistical Analysis}

Quantitative characters were analyzed for their minimum, maximum, mean and standard deviation values and significance using the Statistica version 13.3 software. Importance of differences was tested using oneway Analysis of Variance (ANOVA) with Tukey's honestly significant difference (HSD) post-hoc test for multiple comparisons (Sokal \& Rohlf, 1995).

\section{Results}

The data resulting from morphometric analysis are given in Tab. 1. LM and SEM micrographs showing the pericarp ultrastructure of S. napifolia and S. russelii are presented in Figs. 1-2. Box-and-whisker plots of quantitative characters, such as the thickness of the pericarp, mucilaginous layer, mesocarp, and sclerenchymatous region and size of endocarp cells, are provided in Fig. 3.

The results obtained from detailed LM and TEM studies on the pericarp ultrastructure of the species examined show that the pericarp varies between 70.71 and $140.44 \mu \mathrm{m}$ in thickness, apart from mucilagecontaining cells. It is distinguished into four main regions: the exocarp (epicarp or outer epidermis), mesocarp, sclerenchyma region, and endocarp (inner epidermis) (Figs. 1-2).

The exocarp, the outermost layer of the pericarp, is epidermal in origin and usually comprises isodiametric to elongated, large, thick-walled, and colourless mucilagious cells in groups of one or more. Occasionally, it is also composed of smaller and dark brown nonmucilaginous cells. The mucilaginous cells that produce mucilage upon wetting exhibit a moderate reaction. The thickness of the mucilage region ranges from 0.14 to 0.34 mm (Figs. 1a-d; 2 a-d).

The mesocarp is 35.90-70.45 $\mu \mathrm{m}$ thick and consists of a dark amorphous mass of strongly compressed and tangentially elongated, thicked-walled sclerenchymatous cells and thin-walled parenchymatous cells. The innermost layer of the mesocarp is formed by prismatic crystals of calcium oxalate (Figs. 1a-c, e, h; 2a, b, e-g) 

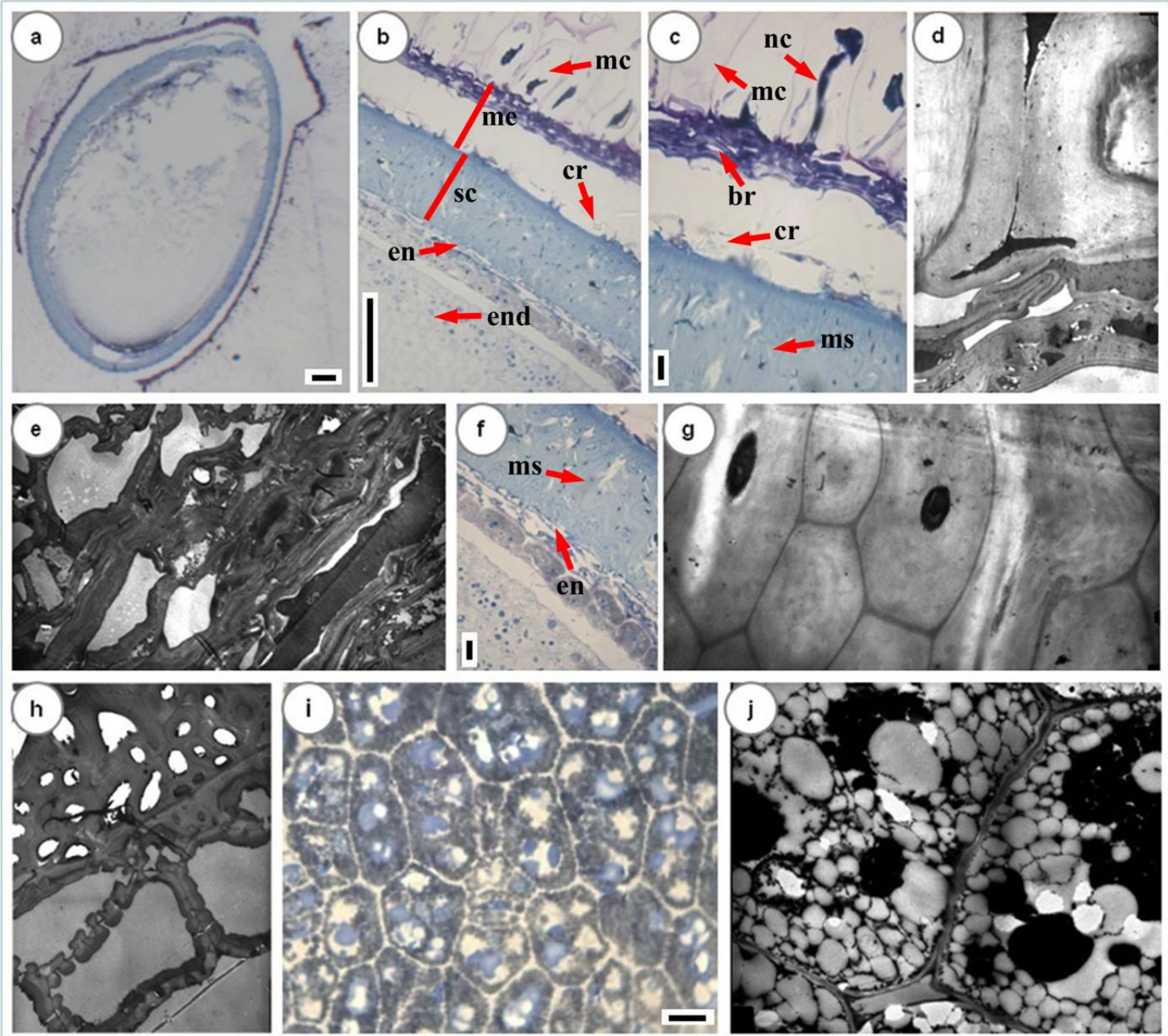

Figure 1: LM and TEM micrographs showing the pericarp ultrastructure of Salvia napifolia Jacq. a. General appearance of cellular layers forming the mericarp. $\mathbf{b}$. General appearance of cellular layers in the pericarp and the endosperm (arrows). c. Mucilaginous and nonmucilaginous cells in the exocarp, brachysclereids in the outermost layer of the mesocarp, large crystals in the innermost layer of the mesocarp, and macrosclereids in the sclerenchyma region (arrows). d. Mucilaginous cells in the exocarp. e. Sclerenchymatous cells in the outermost layer of the mesocarp. f. Macrosclereids in the sclerenchyma region and endocarp cells (arrows). g. Macrosclereids in the sclerenchyma region. $\mathbf{h}$. Bordered pits in the wall of sclerenchymatous cells in the mesocarp. i-j. Endosperm cells filled with nutrients. Abbreviations: $\mathrm{br}=$ brachysclereid, $\mathrm{cr}=$ crystal, $\mathrm{en}=$ endocarp, end $=$ endosperm, $\mathrm{mc}=$ mucilaginous cells, $\mathrm{me}=$ mesocarp, $\mathrm{ms}=$ macrosclereid, $\mathrm{nc}=$ non-mucilaginous cells, $\mathrm{sc}=$ sclerenchyma region. Scale bars for LM micrographs: $\mathrm{a}=100 \mu \mathrm{m}, \mathrm{b}, \mathrm{f}=10 \mu \mathrm{m}, \mathrm{c}=50 \mu \mathrm{m}$, $\mathrm{i}=20 \mu \mathrm{m}$.

Table 1: Morphometric data related to the pericarp ultrastructure of the species studied. Numbers refer to minimum-maximum (mean \pm standard deviation). In case of a significant ANOVA, different superscript letters in each column indicate which taxa significantly differ from each other $(\mathrm{p}<0.001)$. Taxa sharing identical letters are not significantly different $(\mathrm{P} \geq 0.001)$.

\begin{tabular}{|c|c|c|c|c|c|c|}
\hline Species & $\begin{array}{l}\text { Pericarp thickness } \\
\qquad(\mu \mathrm{m})\end{array}$ & $\begin{array}{l}\text { Mucilaginous layer } \\
\text { thickness (mm) }\end{array}$ & $\begin{array}{c}\text { Mesocarp } \\
\text { thickness }(\mu \mathrm{m})\end{array}$ & $\begin{array}{l}\text { Sclerenchyma } \\
\text { region thickness } \\
(\mu \mathrm{m})\end{array}$ & $\begin{array}{l}\text { Endocarp cell } \\
\text { length }(\mu \mathrm{m})\end{array}$ & $\begin{array}{c}\text { Endocarp cell } \\
\text { width }(\mu \mathrm{m})\end{array}$ \\
\hline S. napifolia & $\begin{array}{c}100.87-140.44 \\
(123.43 a \pm 13.40)\end{array}$ & $\begin{array}{c}0.19-0.34 \\
(0.25 a \pm 0.05)\end{array}$ & $\begin{array}{c}43.27-70.45 \\
(53.66 a \pm 7.61)\end{array}$ & $\begin{array}{c}50.17-85.70 \\
(67.83 a \pm 11.52)\end{array}$ & $\begin{array}{c}3.08-6.28 \\
(4.81 \mathrm{a} \pm 1.13)\end{array}$ & $\begin{array}{c}9.01-18.58 \\
(13.52 \mathrm{a} \pm 3.07)\end{array}$ \\
\hline S. russellii & $\begin{array}{c}70.71-98.28 \\
(81.22 \mathrm{~b} \pm 9.27)\end{array}$ & $\begin{array}{c}0.14-0.23 \\
(0.18 b \pm 0.03)\end{array}$ & $\begin{array}{c}35.90-48.07 \\
(41.33 \mathrm{~b} \pm 4.10)\end{array}$ & $\begin{array}{l}38.83-52.09 \\
(45.16 \mathrm{~b} \pm 54)\end{array}$ & $\begin{array}{c}3.64-5.99 \\
(4.71 \mathrm{a} \pm 0.81)\end{array}$ & $\begin{array}{c}7.13-17.32 \\
(12.16 a \pm 3.21)\end{array}$ \\
\hline
\end{tabular}

The mesocarp is followed by a sclerenchymatous region mostly composed of vertically arranged and thickwalled macrosclereid cells. In the lumen, there occurs a cavity at the centre or below the centre of the cells. The thickness of the sclerenchyma region varying between 38.83 and $85.70 \mu \mathrm{m}$ is approximately half of the total pericarp thickness (Figs. 1a-c, f, g; 2a, b, g-i).
Below the sclerenchyma region, there is a single layer of transversely arranged endocarp cells with a length of 3.08-6.28 $\mu \mathrm{m}$ and a width of 7.13-18.58 $\mu \mathrm{m}$ (Figs. $1 \mathrm{a}, \mathrm{b}, \mathrm{f} ; 2 \mathrm{a}, \mathrm{b}, \mathrm{g}$, i). The testa (seed coat), enveloping the endosperm and embryo, is composed of 3-5 layers of thick-walled brachysclereids. The endosperm, a nutrientrich tissue, is composed of parenchymatous cells that are mostly rounded in shape (Figs. 1a, b, i, j; 2a, b, i-k). 

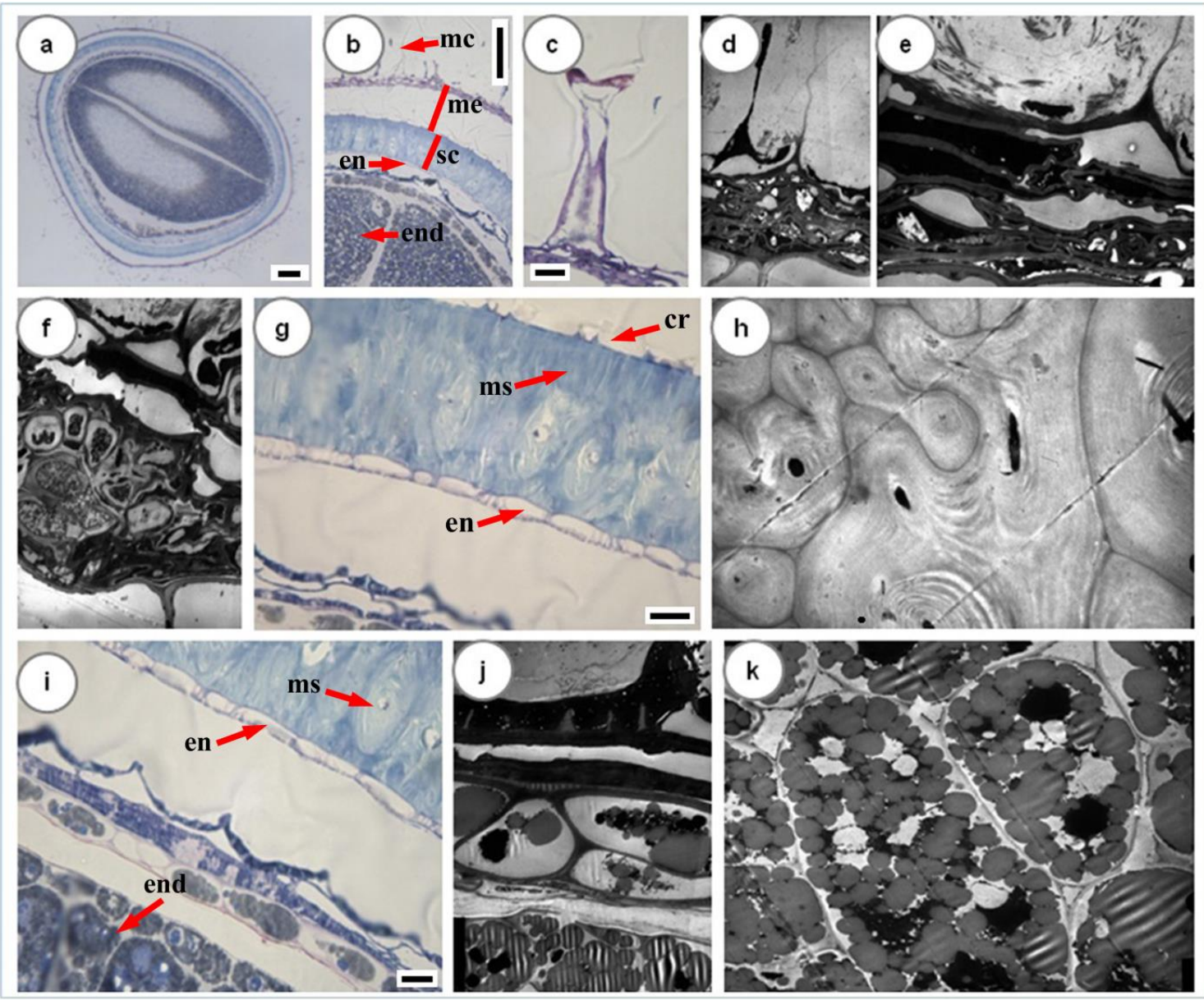

Figure 2: LM and TEM micrographs of the pericarp ultrastructure of Salvia russellii Benth. a. General appearance of cellular layers forming the mericarp. b. General appearance of cellular layers in the pericarp and the endosperm (arrows). c-d. Mucilaginous cells in the exocarp. e-f. Sclerenchymatous cells in the outermost layer of the mesocarp. g. Large crystals in the innermost layer of the mesocarp, macrosclereids in the sclerenchyma region, and endocarp cells (arrows). h. Macrosclereids in the sclerenchyma region. i. Macrosclereids in the sclerenchyma region, endocarp cells, and the endosperm (arrows). j-k. Endosperm cells filled with nutrients. Abbreviations: $\mathrm{cr}=$ crystal, en = endocarp, end $=$ endosperm, $\mathrm{mc}=$ mucilaginous cells, me $=$ mesocarp, $\mathrm{ms}=$ macrosclereid, $\mathrm{sc}=$ sclerenchyma region. Scale bars for LM micrographs: $\mathrm{a}=100 \mu \mathrm{m}, \mathrm{b}=50 \mu \mathrm{m}, \mathrm{c}=20 \mu \mathrm{m}, \mathrm{g}, \mathrm{i}=10 \mu \mathrm{m}$.
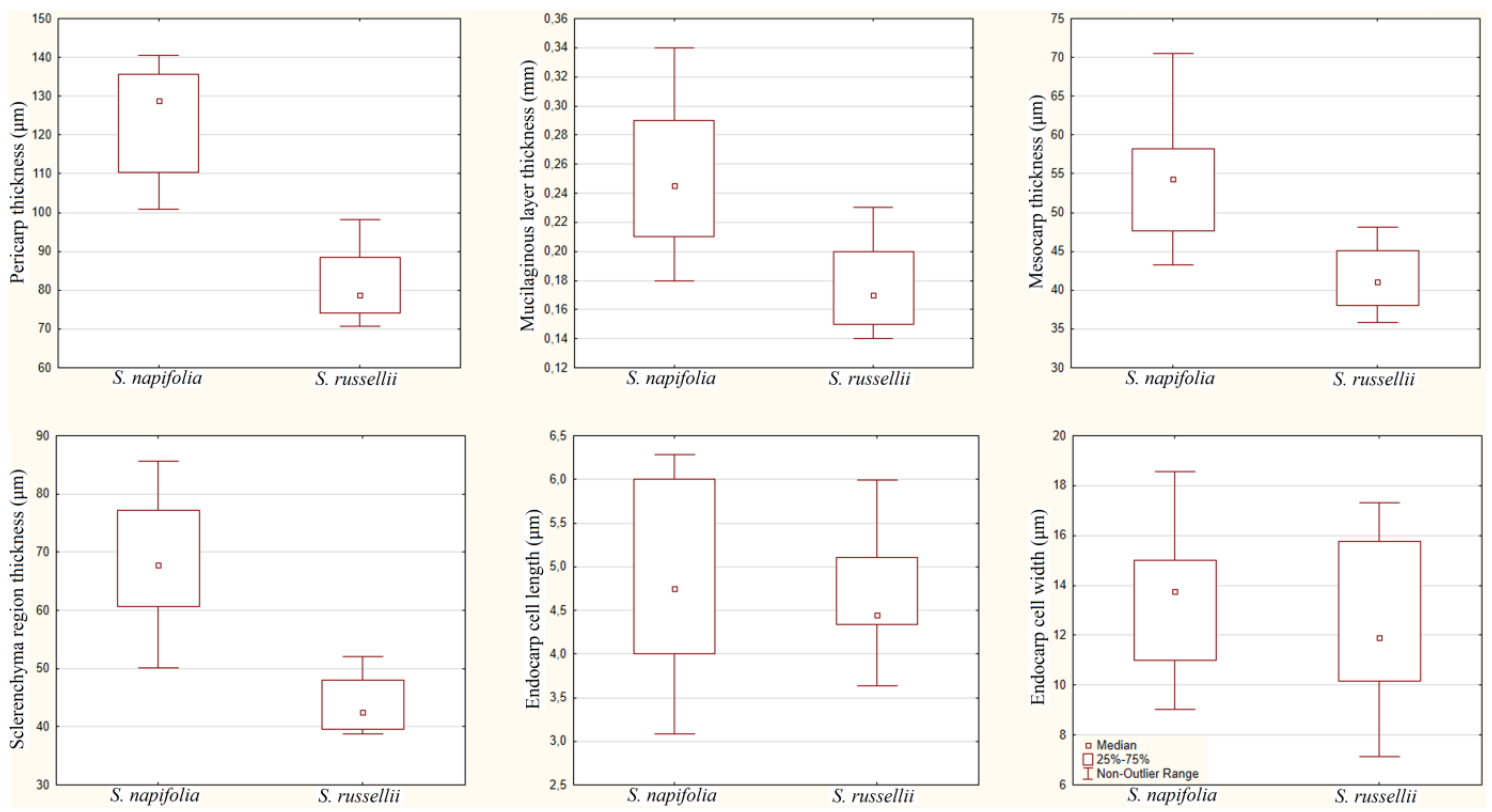

Figure 3: Box-and-whisker plots of quantitative characters of the species studied. 


\section{Discussion}

The pericarp ultrastructure of various genera in the family Lamiaceae has been investigated and the valuable of the pericarp characteristics in the classification of this family has been pointed out by some authors (i.e. Wojciechowska, 1958, 1961a, b, 1966; Makarova, 1967; Ryding, 1992a, b, 1993a, b, 1995, 2001, 2010; Budantsev \& Lobova, 1997; Duletić-Lauševic \& Marin, 1999; Moon \& Hong, 2006). Differences in anatomical structure of the mericarps between some genera of the tribe Nepeteae are recognized (Makarova, 1967). The Nepeteae is also divided into three informal generic groups on the basis of a combination of mericarp morphology, pericarp structure, and vegetative and floral features (Budantsev \& Lobova, 1997). The groups of Prunella L. and Cleonia L. plus Lepechinia Willd. and Chaunostoma Donn. Sm. are separated by differences in pericarp structure from other genera in the Lamiaceae (Ryding, 1995). Mericarp morphological and anatomical characters of Lycopus are useful as diagnostic characters at the specific and interspecific levels (Moon \& Hong, 2006). Much of the variation in pericarp structure of the tribe Mentheae has been remarked to be strongly correlated to the variations in DNA and gross morphology (Ryding, 2010). In spite of the above-mentioned information on the pericarp structure of the family Lamiaceae and its taxonomic significance, the data on that of the genus Salvia are still incomplete. To date, the pericarp ultrastructure of Salvia has been rarely studied (Wojciechowska, 1958, 1966; Hedge, 1970; Oran, 1997; Ryding, 2010; Büyükkartal et al., 2011; Hassan \& Al. Thobaiti, 2014). Characters of the pericap ultrastructure, such as the presence of myxocarpy, the thickness of the pericarp as well as the proportions of its individual layers, have been found to be useful for the systematics of Salvia (Hedge, 1970). The groups of two-staminate genera, as in Salvia, and fourstaminate genera of Salviinae, as in Lepechinia and Chaunostoma, can be separated from each other and from other Lamiaceae genera by differences in pericarp structure (Ryding, 2010). Variations in the pericarp structure have been pointed out to be helpful in the identification of morphologically similar Salvia species (Büyükkartal et al., 2011). In this study, the pericarp of $S$. napifolia is observed to be significantly thicker than that of S. russellii. According to Duletić-Lauševic and Marin (1999), the pericarp thickness in the tribe Nepetoideae of the Lamiaceae usually correlates with dimensions of mericarps. However, Mentha aquatica L. is a very thick pericarp (ca. $95 \mu \mathrm{m}$ ) though it has very small mericarps (ca. $0.8 \mathrm{~mm} \times 0.6 \mathrm{~mm}$ ). Mericarps of $S$. napifolia and $S$. russellii are similar in size (ca. 2.5 x $1.5 \mathrm{~mm}$; Hedge, 1982) but there is an important variation between them in terms of the pericarp thickness.

Myxocarpy is widely observed in the subfamily Nepetoideae (Wagner, 1914; Hedge, 1970; Swarbrick, 1971; Witztum, 1978; Ryding, 1992a, 2001, 2010; DuletićLauševic \& Marin, 1999; Harley et al., 2004). Morphologically allied species have similar mucilage properties (Hedge, 1970). In this study, both species produce mucilage on their mericarps but $S$. napifolia seems to have a somewhat thicker mucilaginous layer than S. russellii. The mucilage formation is detected in nearly all of over forty Salvia species in Southwest Asia, except for only three species (Hedge, 1970). These mucilage-producing species can be grouped into four basic types according to the extent of swelling of mucilaginous cells (Ryding, 1992a). A moderately strong mucilaginous reaction is seen in Elsholtzia blanda Benth. in the tribe Elsholtzieae but there is no mucilage on the mericarp surface of Lycopus taxa (Moon \& Hong, 2006). Our results show that a moderately mucilaginous reaction is recognized on the pericarp surface of both species but stronger in S. napifolia. According to Oran (1997), the occurrence of mucilage is observed in most of Salvia species in Jordan but $S$. napifolia sometimes produces a very small amount or no visible mucilage. According to our detailed study carried out to determine the presence/absence of the mucilage formation, we conclude that Oran's (1997) report is obviously incorrect.

In Lycopus europaeus and Mentha aquatica, the mesocarp consists of aerenchymatous cells (Ryding, 2010). However, these cells are absent in the mesocarp of the Salvia species examined. Two-staminate Salviinae, except a few of the species (i.e. Salvia splendens F. Sellow ex Roem. \& Schult. and Perovskia abrotanoides Kar.), can be distinguished from four-staminate Salviinae and other Mentheae by having large crystals in the innermost cell layer of the mesocarp (Ryding, 2010). Our investigation reveals that the species have large prismatic crystals in the innermost cell layer of the mesocarp. The sclerenchyma region is found in most genera of the Lamiaceae (Ryding, 1995). The presence of such a region in the Salvia species disagrees with the situation in some genera, such as Chelonopsis Miq., Renschia Vatke, and Scutellaria $\mathrm{L}$. The Salviinae with four stamens differs from the two-staminate Salviinae $(3-9 \mu \mathrm{m})$ and other Mentheae $(2-12 \mu \mathrm{m})$ in having a thicker endocarp (17-40 $\mu \mathrm{m})$ (Ryding, 2010). In this study, the endocarp of the species is similar in thickness (ca. 3-6 $\mu \mathrm{m}$ ).

Though the species studied have similarities in their gross morphology, important differences in morphometric characters, such as the thickness of the pericarp $(p=0.000)$, mesocarp $(p=0.000)$, sclerenchyma region $(p=0.000)$, and mucilaginous layer $(p=0.000)$, are found between them (Tab. 1). They have leaves simple, calyces thick-texture, upper lip not concave and not 2sulcate in fruit, upper lip of corolla more or less straight, corolla tube annulate and not squamulate, and stamens type C (staminal connectives longer than the filaments, lower theca subulate and stamens not articulating). Although these species agree in having thick endocarp and crystals in the sclerenchyma region, S. napifolia are obviously distinct from $S$. russelii based on other pericarp characteristics, the particularly thicker pericarp, mesocarp, and sclerenchyma region.

In summary, there have been no detailed investigations on the pericarp of S. napifolia and S. russellii even though ultrastructural studies can be used as a powerful tool in delimitation of species. Thus, this study is the first comprehensive report on their pericarp ultrastructure. We hope that the present study further puts emphasis on the value of the pericarp ultrastructure for plant systematics and will encourage future investigations of Salvia species. In view of a lack of knowledge of pericarp ultrastructure and differentiation in Salvia, this is definitely a research field requiring further study. 
Acknowledgments: This work was financially supported in part by the Scientific and Technical Research Council of Turkey (Project Number: 104 T 450). Material of L. napifolia was provided by Dr. F. Celep (Ankara, Turkey). We would like to give special thanks to the curators of the herbaria ANK, AEF, BM, E, G, GAZI, HUB, ISTE, ISTF, K, P and $\mathrm{W}$ for allowing us to study their Salvia collections. Furthermore, they would like to thank the anonymous reviewers for their valuable comments and constructive suggestions.

\section{References}

Baytop, T. (1999). Therapy with Medicinal Plants in Turkey (Past and Present). İstanbul, Turkey, Nobel Medical Presshouse, 480 pp.

Bilimovitsch, O. (1935). On the structure of the pericarp in the Labiatae from a systematic viewpoint. Trudy Voronezhsk. Gosud. Univ., 7, 68-84.

Boissier, E. (1879). Flora Orientalis, vol. 4. Bassel \& Genéve, 1276 pp.

Budantsev, A.L. (1993a). Ultrastructural features of fruit surface in genus Nepeta (Lamiaceae). Botanicheskii Zhurnal, 78(4), 80-87.

Budantsev, A.L. (1993b). The ultrastructural features of fruit surface in some genera of the tribe Nepeteae (Lamiaceae). Botanicheskii Zhurnal, 78(5), 100-108.

Budantsev, A.V., \& Lobova, T.A. (1997). Fruit morphology, anatomy and taxonomy of tribe Nepeteae (Labiatae). Edinburgh Journal of Botany, 54(2), 183-216. https://doi.org/10.1017/S0960428600004029

Büyükkartal, H.N., Kahraman, A., Çölgeçen, H., Doğan, M., \& Karabacak, E. (2011). Mericarp micromorphology and anatomy of Salvia hedgeana Dönmez, S. huberi Hedge and S. rosifolia Sm. (section Salvia Hedge, Lamiaceae). Acta Botanica Croatica, 70(1), 65-80. https://doi.org/10.2478/v10184-010-0011-8

Davis, P.H., \& Heywood, V.H. (1973). Principles of Angiosperm Taxonomy. Huntington, New York, Robert E. Kieger Publishing Co., $558 \mathrm{pp}$.

Doğan, M., Akaydın, G., Celep, F., Bagherpour, S., Kahraman, A., \& Karabacak, E. (2007). Infrageneric delimitation of Salvia L. (Labiatae) in Turkey. Proceedings 7 th International Symposium on Plant Life of Southwest Asia. Eskişehir, Turkey.

Duletić-Lauševic, S., \& Marin, P.D. (1999). Pericarp structure and myxocarpy in selected genera of Nepetoideae (Lamiaceae). Nordic Journal of Botany, 19(4), 435-446. https://doi.org/10.1111/j.17561051.1999.tb01227.x

Er, M., Tugay, O., Özcan, M.M., Ulukuş, D., \& Al-Juhaimi, F. (2013). Biochemical properties of some Salvia L. species. Environmental Monitoring and Assessment, 185(6), 5193-5198. https://doi.org/10.1007/s10661-012-2935-z

Guerin, G.R. (2005). Nutlet morphology in Hemigenia R. Br. and Microcorys R. Br. (Lamiaceae). Plant Systematics and Evolution, 254(1-2), 49-68. https://doi.org/10.1007/s00606-005-0311-y

Harley, R. M., Atkins, S., Budantsev, A., Cantino, P.D., Conn, B.J., Grayer, R., Harley, M.M., ... Upson, T. (2004). Labiatae. In K. Kubitzki, (Ed.), The Families and Genera of Vascular Plants, vol. 7 (pp. 167-275). Heidelberg, Berlin, Springer-Verlag.

Hassan, S.A., \& Al. Thobaiti, A.T. (2014). II. Pericarp anatomical study of some Lamiaceae nutlets in Saudi Arabia and its taxonomic significance. Pakistan Journal of Botany, 46(5), 1643-1651.

Hedge, I.C., Lamond, J. (1968). Studies in the flora of Afghanistan: VII, Labiatae. Notes from the Royal Botanic Garden Edinburgh, 28, 97-123.

Hedge, I.C. (1970). Observations on the mucilage of Salvia fruits. Notes from the Royal Botanic Garden Edinburgh, 30, 79-95.

Hedge, I.C. (1982). Flora of Turkey and the East Aegean Islands. In P.H. Davis, (Ed.), Salvia L., vol. 7 (pp. 400-461). Edinburgh, UK, Edinburgh University Press, $947 \mathrm{pp}$.

Kirmizibekmez, H., Bardakci Altan, H., Liktor-Busa, E., Zana, A., Yesilada, E., \& Hohmann, J. (2012). Chemical constituents of Salvia dichroantha. Biochemical Systematics and Ecology, 42, 18-20. https://doi.org/10.1016/j.bse.2012.01.001

Kotan, R., Kordali, S., Cakir, A., Kesdek, M., Kaya, Y., \& Kilic, H. (2008). Antimicrobial and insecticidal activities of essential oil isolated from Turkish Salvia hydrangea DC. ex Benth. Biochemical Systematics and Ecology, 36(5-6), 360-368. https://doi.org/10.1016/j.bse.2007.12.003
Luft, J.H. (1961). Improvements in epoxy resin embedding methods. Journal of Biophysical and Biochemical Cytology, 9(2), 409-414. https://doi.org/10.1083/jcb.9.2.409

Makarova, Z.I. (1967). On the significance of the anatomical structure of the pericarp for the taxonomy of the tribe Nepeteae. Botanicheskii Zhurnal, 52, 33-41.

Moon, H.K., \& Hong, S.P. (2006). Nutlet morphology and anatomy of the genus Lycopus (Lamiaceae. Mentheae). Journal of Plant Research, 119(6), 633-644. https://doi.org/10.1007/s10265-006-0023-6

Mosquero, M.A.M., Juan, R., Pastor, J.E. (2002). Morphological and anatomical studies on nutlets of Nepeta L. (Lamiaceae) from SouthWest Spain. Acta Botanica Malacitana, 27, 15-25.

Oran, S.A. (1997). Nutlet anatomy of the genus Salvia L. in Jordan. Flora Mediterranea, 7, 27-40.

Ryding, O. (1992a). The distribution and evolution of myxocarpy in Lamiaceae. In R.M., Harley, \& T. Reynolds, T. (Eds.), Advances in Labiatae Science (pp. 85-96). Royal Botanic Gardens, Kew, UK.

Ryding, O. (1992b). Pericarp structure and phylogeny within Lamiaceae subfamily Nepetoideae tribe Ocimeae. Nordic Journal of Botany, 12(3), 273-298. https:// doi.org/10.1111/j.1756-1051.1992.tb01304.x

Ryding, O. (1993a). Pericarp structure and systematic positions of five genera of Lamiaceae subg. Nepetoideae tribe Ocimeae. Nordic Journal of Botany, 13(6), 631-635. https://doi.org/10.1111/j.17561051.1993.tb00107.x

Ryding, O. (1993b). Pericarp structure of Leucas and related genera (Lamiaceae subfam. Lamioideae). Nordic Journal of Botany, 13(6), 637646. https://doi.org/10.1111/j.1756-1051.1993.tb00108.x

Ryding, O. (1995). Pericarp structure and phylogeny of the LamiaceaeVerbenaceae-complex. Plant Systematics and Evolution, 198(1-2), 101141. https://doi.org/10.1007/bf00985109

Ryding, O. (2001). Myxocarpy in the Nepetoideae (Lamiaceae) with notes on myxodiaspory in general. Systematics and Geography of Plants, 71(2), 503-514. https://doi.org/10.2307/3668696

Ryding, O. (2010). Pericarp structure and phylogeny of tribe Mentheae (Lamiaceae). Plant Systematics and Evolution, 285(3-4), 165-175. https://doi.org/10.1007/s00606-010-0270-9

Sato, J.E. (1968). A modified method for lead staining of thin sections. Journal of Electron Microscopy, 17(2), 158-159. https://doi.org/10.1093/oxfordjournals.jmicro.a049610

Sokal, R., \& Rohlf, F.J. (1995). Biometry: The Principles and Practice of Statistics in Biological Research. New York, W.H. Freeman \& Company, $887 \mathrm{pp}$.

Stempak, J.G., \& Ward, W.P. (1964). An improved staining method for electronmicroscopy. Journal of Cell Biology, 22(3), 697-701. https://doi.org/ 10.1083/jcb.22.3.697

Swarbrick, J.T. (1971). External mucilage production by seeds of British plants. Botanical Journal of the Linnean Society, 64(2), 157-162. https://doi.org/10.1111/j.1095-8339.1971.tb02142.x

Topcu, G., Turkmen, Z., Schilling, J.K., Kingston, D.G. I., Pezzuto, J.M., \& Ulubelen, A. (2008) Cytotoxic activity of some Anatolian Salvia extracts and isolated abietane diterpenoids. Pharmaceutical Biology, 46(3): 180184. https://doi.org/10.1080/13880200701735411

Ulubelen, A. (2003). Cardioactive and antibacterial terpenoids from some $\begin{array}{llll}\text { Salvia } & \text { species. } & \text { 395-399. }\end{array}$ https://doi.org/10.1016/s0031-9422(03)00225-5

Wagner, S. (1914). Contribution à l'étude anatomique du fruit des Labiées. (PhD Thesis). Université de Paris, Lons-le-Saunier, France.

Walker, J.B., \& Sytsma, K.J. (2007). Staminal evolution in the genus Salvia (Lamiaceae): molecular phylogenetic evidence for multiple origins of the staminal lever. Annals of Botany, 100(2), 375-391. https://doi.org/10.1093/aob/mcl176

Witztum, A. (1978). Mucilaginous plate cells in the nutlet epidermis of Coleus blumei Benth. (Labiatae). Botanical Gazette, 139(4), 430-435. https://doi.org/10.1086/337018

Wojciechowska, B. (1958). Taxonomy, morphology and anatomy of fruits and seeds in the genus Salvia L. Monographiae Botanicae, 6, 3-55. 
Wojciechowska, B. (1961a). Fruits of the Middle European species of

Prunella L. (fam. Labiatae), theier morphology and anatomy. Monographiae Botanicae, 12, 49-88.

Wojciechowska, B. (1961b). Fruits in the Middle European species of some genera of Stachyoideae (fam. Labiatae). Monographiae Botanicae, 12, 89120.

Wojciechowska, B. (1966). Morphology and anatomy of fruits and seeds in the family Labiatae with particular respect to medicinal species. Monographiae Botanicae, 21, 3-244.

Wojciechowska, B. (1972). Fruit morphology and anatomy inScutellaria, Chaiturus, Galeobdolon and Sideritis of the family Labiatae. Monographiae Botanicae, 37, 137-169. 